\title{
MODUL UNIT KARANTINA PORTABLE SEBAGAI FASILITAS PEMBANTU RUANG ISOLASI DARURAT DI LINGKUNGAN KAMPUNG PADAT PENDUDUK
}

\author{
Yusuf Ariyanto $^{{ }^{*}}$, Wira Widjaya Lindarto ${ }^{2}$, Dyah Kusuma Wardhani ${ }^{3}$ \\ 1,2,3 Universitas Ciputra Surabaya, Citra Land CBD Boulevard, Kota Surabaya, \\ Jawa Timur 60219 \\ *Penulis korespondensi; email: yusuf.ariyanto@ciputra.ac.id
}

\begin{abstract}
Abstrak: Kapasitas ruang isolasi di Rumah Sakit yang ditunjuk Pemerintah untuk merawat pasien Covid-19 sudah tak mampu menampung membeludaknya pasien positif Covid-19. Pasien positif Covid-19 yang belum mengalami atau bahkan yang tidak menunjukkan gejala penurunan kondisi fisik, dianjurkan untuk melakukan karantina dan perawatan secara mandiri. Karantina secara mandiri ini menjadi tantangan tersendiri untuk permukiman padat penduduk, terutama permukiman informal. Menjadi studi kasus pada kegiatan pengabdian masyarakat ini adalah permukiman informal yang berada di tepi kereta api. Bersama tim ARKOM Surabaya sebagai mitra melakukan observasi lapangan dengan hasil menunjukkan bahwa kondisi rumah yang memprihatinkan masih banyak terdapat di area ini, kondisi rumah berdempetan dan tidak sesuai standar rumah sehat inilah yang menyebabkan potensi besar penularan Covid-19 dan tidak memungkinkan untuk melakukan isolasi mandiri di rumah masing-masing. Solusi yang ditawarkan adalah membuat modul ruang karantina komunal sebagai ruang karantina darurat bagi masyarakat kampung informal pada masa pandemi atau kondisi darurat tertentu dengan metode desain partisipatif yang memenuhi standar kesehatan untuk sebuah ruang karantina yang didesain dengan proses aplikasi modul yang mudah, murah dan cepat. Tujuan dari kegiatan ini adalah memberikan modul unit karantina komunal sebagai prototype yang dapat dibuat sendiri oleh masing-masing kampung padat penduduk dengan sistem yang sederhana (portable), material mudah didapat, cepat dan mengedepankan usaha partisipatif masyarakat dalam pembuatannya.
\end{abstract}

Kata kunci: Ruang Isolasi, Modul Unit, Covid-19, Partisipatif

\begin{abstract}
The capacity of the isolation room at the hospital appointed by the Government to treat Covid-19 patients is no longer able to accommodate the positive Covid-19 patients. Positive Covid19 patients with no symptoms or other signs of worsening physical conditions are advised to do self-quarantine and isolation independently. This self-quarantine/isolation becomes a problem especially in densely populated settlements, especially informal settlements. The case study on this community service activity is an informal settlement located along the Surabaya railroad. Together with the Surabaya ARKOM team as partners, this community service activity conducting field observations with the results that there are still many poor house conditions in this area, the conditions of the houses are tight and not fulfilled the standards of a healthy house, which causes a larger potential spread of Covid-19 virus and makes it impossible to carry out selfisolation in their each homes. The solution offered is to create a communal isolation room module as an emergency isolation room for informal village communities during a pandemic or can be used in other certain emergency conditions with a participatory design method that meets health standards for isolation rooms designed with the easy and fast module applications process. The purpose of this activity is to provide a set of modules for communal quarantine units as prototypes that can be made by the community with a simple system (portable), easily available materials, fast and prioritizing community participation in its assembling.
\end{abstract}

Keywords: Isolation Room, Unit Module, Covid-19, Participatory.

\section{PENDAHULUAN}

Pandemi Covid-19 mewabah diseluruh dunia dengan angka penularan yang relatif tinggi dan berpengaruh secara global (Wu et al., 2020), di- tambah dengan kewaspadaan warga khususnya warga Indonesia yang masih cenderung kurang. Vaksin untuk Covid 19 sampai saat ini masih dalam fase uji klinik, dan belum ditemukan obat untuk penyembuhannya sehingga salah satu cara 
untuk melawan virus ini adalah dengan mengisolasi orang yang terinfeksi untuk mengurangi penyebaran virus (World Health Organization, 2020). Selaras dengan hal tersebut, kapasitas ruang isolasi di Rumah Sakit yang ditunjuk Pemerintah untuk merawat pasien Covid-19 sudah tak mampu menampung membeludaknya pasien positif Covid19. Langkah Pemerintah selanjutnya adalah Rumah Sakit-Rumah Sakit yang ditunjuk tersebut hanya akan merawat pasien positif Covid-19 yang sudah mengalami penurunan kesehatan fisik disertai penyakit bawaan yang diakibatkan dari virus tersebut serta memerlukan perawatan medis yang intens. Berdasarkan kajian yang ada, hanya $20 \%$ pasien terinfeksi yang memerlukan perawatan di rumah sakit, sedangkan $80 \%$ yang karantina mandiri dan isolasi diri di rumah yang hal ini merupakan tugas Puskesmas bersama lintas sektor yang terlibat sebagai Tim Satgas Covid-19 Kecamatan/Desa/Kelurahan untuk melakukan pengawasan. (Widodo, 2020).

Pernyataan WHO tentang Covid-19 dapat menyebar melalui mikrodoplets atau aerosol, menjadi penekanan pentingnya pemakaian masker sebagai cara paling efektif untuk mencegah penularan. Selain pemakain masker, ventilasi yang baik diperlukan dalam meminimalisir penyebaran Covid-19 melalui udara.
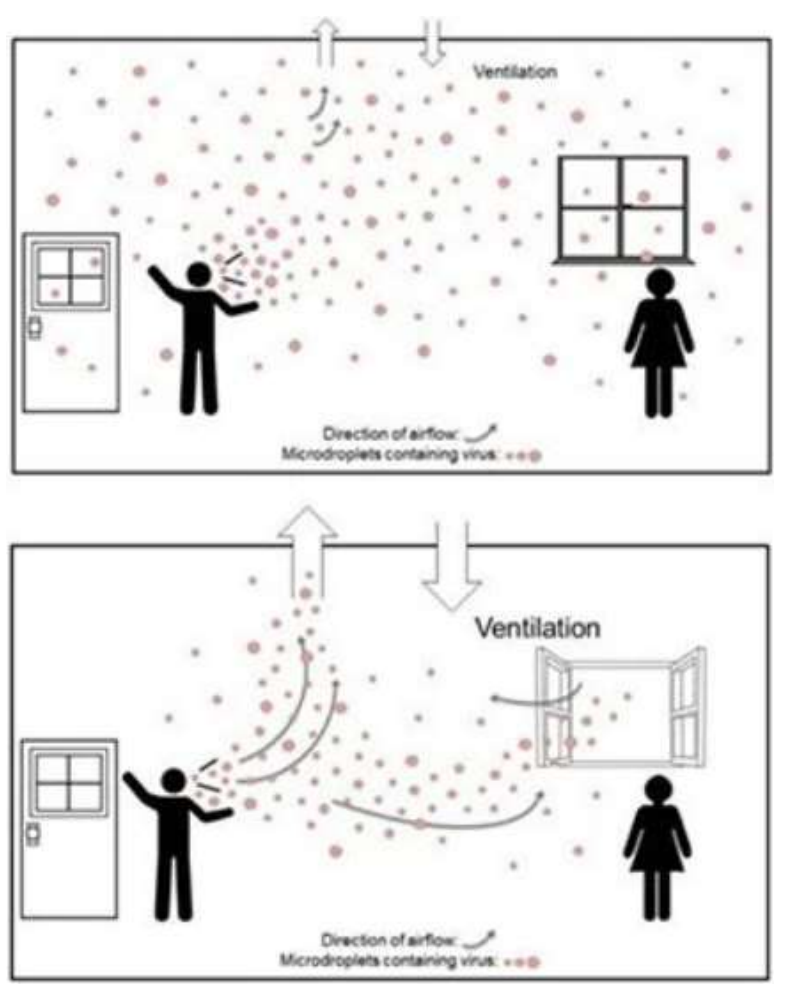

Gambar 1. Kebutuhan ventilasi untuk mengurangi penyebaran virus (Sumber: Morawska \& Milton, 2020)

Kebutuhan ventilasi yang baik perlu didukung dengan adanya udara segar masuk ke dalam ruangan, meminimalisir penggunan $\mathrm{AC}$ supaya tidak terjadi resirkulasi. Penggunaan alat yang dapat membantu menyaring dan mebersihkan udara seperti exhaust, penyaring/filter dan lampu UV untuk sterilisasi serta menghindari kepadatan yang terlalu tinggi pada transportasi umum atau gedung dengan membatasi jumlah orang hingga $50 \%$ pada ruang tertutup (Morawska et al. 2020). Sistem tata udara untuk ruang isolasi memegang peranan penting untuk mengurangi penyebaran agen infeksius dengan penciptaan ruang bertekanan negatif sehingga udara luar dapat masuk ke dalam ruangan dan udara yang keluar dari ruanga melewati HEPA filter terlebih dahulu. Hal ini perlu ditunjang dengan pemeliharaan dan pemeriksaan berkala agar besaran volume, pertukaran dan aliran udara sesuai standar (Sundari et al. 2017).

Ada 5 Persyaratan yang harus dipenuhi ruang isolasi (Listijono 2020):

1. Negative Pressure (Tekanan ruangan yang negatif) untuk mencegah udara ruangan yang infectious tidak keluar ke ruangan lainnya.

2. Jumlah udara luar yang dimasukkan minimum $2 \times \mathrm{ACH}$ s/d 100\% udara luar, untuk melarutkan konsentrasi bakteri/virus didalam ruangan.

3. Distribusi aliran udara tidak boleh dari pasien ke dokter/suster.

4. Temperature ruangan, $\mathrm{RH}$ ruangan dan kebersihan ruangan terjaga, Units AC harus bisa mengatur Temperature, $\mathrm{RH}$ ruangan dan dilengkapi dengan HEPA filter apabila tidak memakai $100 \%$ udara luar serta pengaturan jumlah aliran udara konstan secara otomatis. Hepa filter sendiri berfungsi untuk mengurangi konsentrasi bakteri/virus dengan cara filtration.

5. Memasang exhaust grille di belakang ranjang/ kepala pasien dan exhaust fan nya di pasang Hepa filter untuk mengurangi konsentrasi bakteri/virus dari sumber nya.

Pasien positif Covid-19 yang belum mengalami atau bahkan yang tidak menunjukkan gejala penurunan kondisi fisik, dianjurkan untuk melakukan karantina dan perawatan secara mandiri (dirumah masing-masing) dengan memperhatikan protokol-protokol kesehatan yang dipantau oleh tim medis kesehatan setempat. Kegiatan pengabdian masyarakat ini bekerjasama dengan ARKOM Jatim, yaitu komunitas non-profit yang berkegiatan untuk memberikan dolusi desain secara partisipatif kepada masyarakat terdampak dengan pendekatan sosialisasi. Menurut hasil survei yang dilakukan tim ARKOM-Surabaya menunjukkan bahwa kondisi rumah yang memprihatinkan masih banyak terdapat di wilayah kota Surabaya terutama di area pemukiman informal, Sehingga bila di lingkungan tersebut terdapat PDP atau bahkan orang yang sudah positif Covid-19 maka mereka akan melakukan karantina mandiri yang tidak sesuai 
dengan standar protokol kesehatan, karena standart hunian yang sehatpun belum terpenuhi. Kondisi permukiman padat dengan rumah saling berdempetan yang menjadi sasaran kegiatan adalah di Dupak Magersari - RT 1/RW 9 Jepara, Bubutan dan Ambengan Selatan Karya Kelompok 4-RT 1/RW 5 Pacarkeling, Kota Surabaya.

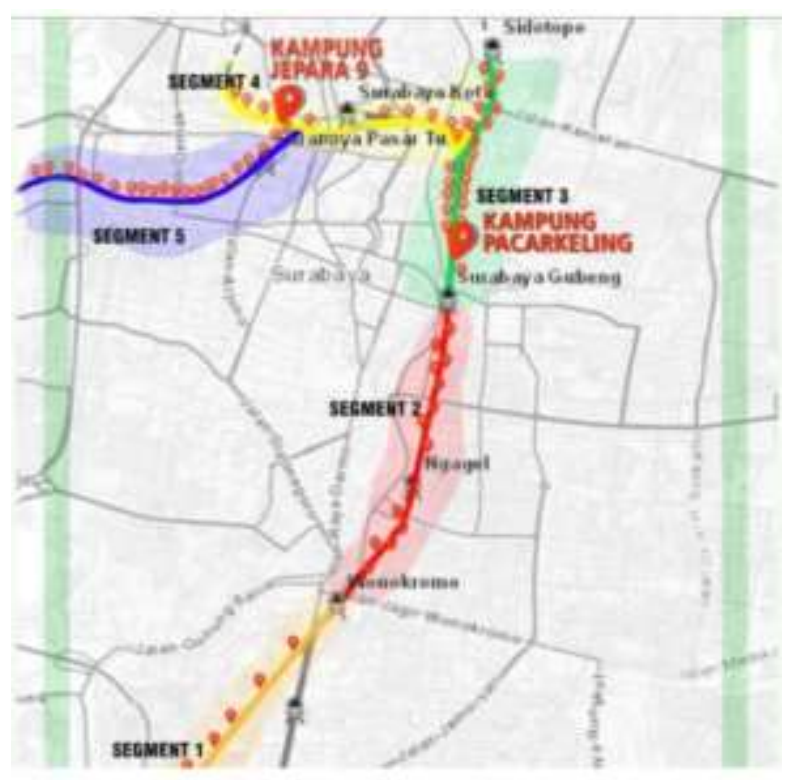

Gambar 2. Lokasi kegiatan (Sumber: ARKOM Jatim)

Penggunaan fasilitas umum sebagai tempat karantina dan/atau isolasi mandiri dapat dilakukan bila kondisi rumah tidak memungkinkan dan tidak ada fasilitas tempat penginapan yang bisa digunakan sebagai safe house. Penggunaan fasilitas umum yang dimaksud disini adalah seperti kantor pemerintah, area olahraga atau balai desa/kelurahan. (Kusmadiana et al., 2020). Untuk mengurangi penyebaran Covid-19 terutama dalam permukiman yang padat terdapat beberapa langkah yang bisa diambil, (1) mendistribusikan bantuan kemanusiaan, (2) memahami bahwa shelter yang tidak memadai dapat meningkatkan resiko penyakit pernapasan dan memperpuruk dampak virus, (3) mengurangi kepadatan pada permukiman dengan menjaga social distancing, (4) Memperluas shelter untuk menampung rumah tangga yang rentan karena padat, (5) merencanakan dan membangun fasilitas kesehatan dan area isolasi yang sesuai dengan kriteria kesehatan. (Cluster, n.d.)

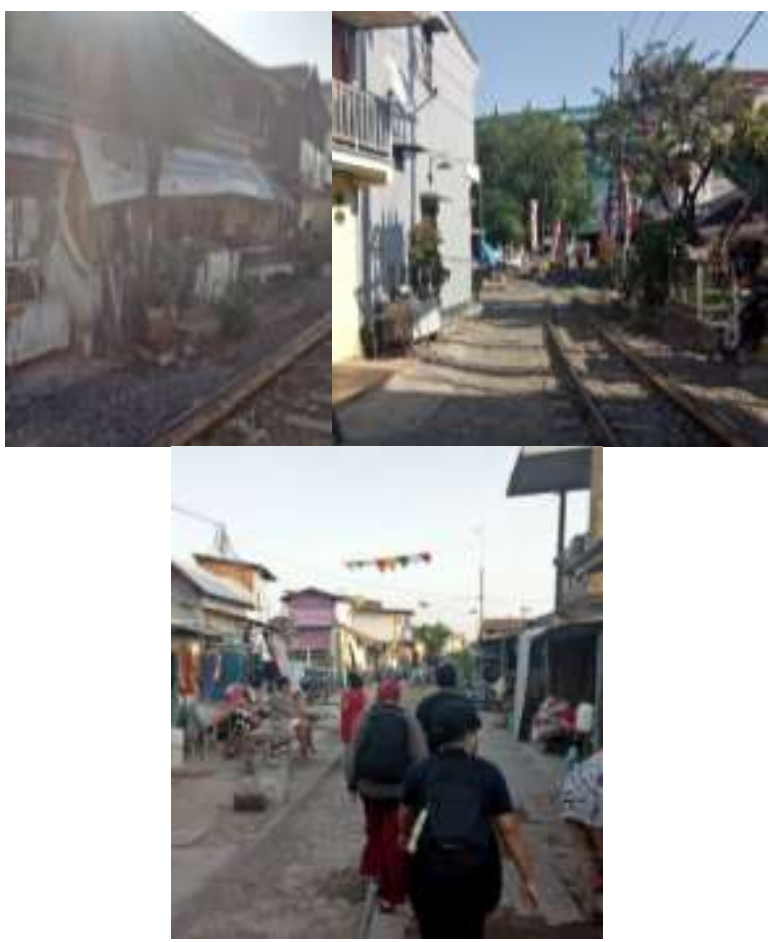

Gambar 3. Suasana permukiman di Kampung Tepi Rel Jepara (Dupak Magersari) dan Kampung Tepi Rel Ambengan.

Sehingga strategi yang yang diusulkan untuk PDP dan pasien positif Covid-19 tanpa gejala di kawasan pemukiman informal padat adalah dengan karantina mandiri dalam skala kelurahan. Dengan pemanfaatan area publik kelurahan sebagai area karantina dan/atau isolasi untuk mengurangi penyebaran dan sebagai langkah awal untuk mendeteksi. Tujuan dari kegiatan pengabdian masyarakat ini adalah menghasilkan usulan modul unit karantina mandiri untuk PDP dan positif tanpa gejala yang sesuai dengan protokol standar kesehatan dan menggunakan sistem portable sehingga mempercepat proses pembangunan dengan partisipasi dari masyarakat.

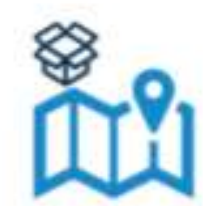

Dustributing essential humanitarian assistance in a way that avoids spreading the disease.

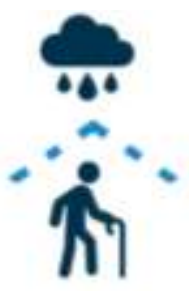

Inadequate shelter car increase respiratory disezses which aggravate the impact of the vins.

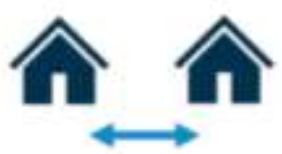

Decongesting and reducing human denuity in: sertements to mainuain social distancing and reduce transmission.

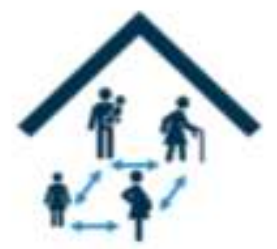

Expanding the shelters of wihecable households io reduce ovescrowding and misigate the norsad of the vinus.

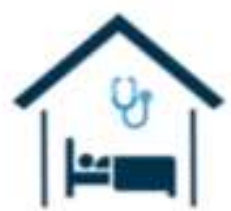

Pianning and bullding isolation areas and medical facilities according to heath criteria.

Gambar 4. Cara untuk mengurangi penyebaran Covid-19 pada permukiman (Sumber: ShelterCluster.org/COVID19) 


\section{METODE PELAKSANAAN}

Metode pelaksanaan kegiatan pengabdian masyarakat ini didasarkan pada proses desain partisipatif dari masyarakat. Menurut Bayerle (2018), proses desain partisipatif merupakan cara yang mampu mengkomunikasikan permasalahan yang ada di masyarakat serta aktifitas yang berdampak dari mereka dan oleh mereka sehingga desain yang dihasilkan senantiasa berkelanjutan. Proses desain partisipatif ini dimulai dengan kegiatan pengumpulan data yang dapat dilakukan dengan survei, observasi atau identifikasi permasalahan secara fisik dan non-fisik serta interview terhadap pihakpihak yang terkait. Setelah itu adalah memasuki tahap pemetaan permasalahan yang menjadi parameter untuk dilakukan solusi dalam bentuk desain, hanya yang menjadi poin yang khas dari metode ini adalah pengambilan solusi dilakukan bersama pihak-pihak terkait dengan mengadakan diskusidiskusi dan penggambaran untuk mempermudah penyampaian informasi. Terakhir adalah pelaksanaan oleh tim sebagai fasilitator yang dilakukan bersama pihak-pihak terkait tersebut sehingga mereka merasa memiliki terhadap desain maupun produk yang dihasilkan.

Metode desain partisipatif dilakukan sebagai kegiatan pengabdian masyarakat ini dilakukan sebagai berikut:

1. Tim ARKOM akan melakukan persiapan meliputi pemilihan lokasi sesuai dengan analisa yang sudah dilakukan sebelum kegiatan.

2. Melakukan diskusi awal dengan warga mengenai isu yang terjadi serta harapan-harapan mereka akan kondisi serta solusi yang diinginkan, selain itu tim survei akan menggali informasi lain sebagai data pendukung (sekunder).

3. Melakukan diskusi dengan pihak terkait isu dalam hal ini adalah satgas-Covid 19 kampung yang ada diwilayah tersebut.

4. Penyusunan tools assessment dari data primer maupun sekunder yang didapat.

5. Tim UC melakukan penyusunan analisa awal berupa desain yang mampu mengakomodasi isu-isu tersebut diatas.

6. Melakukan assessment dari segi standar kesehatan oleh dokter atau ahli bidang kesehatan oleh tim ARKOM dan UC.

7. Melakukan diskusi sosialisasi secara online dengan warga sasaran dengan bermodalkan hasil desain awal sebagai bentuk feedback dari tim ARKOM. Feedback tersebut dapat berupa kuisioner yang disebar kepada warga didaerah tersebut dengan tujuan untuk meminimalkan kontak fisik atau pertemuan-pertemuan sosialisasi.

8. Melakukan revisi guna menanggapi feedback dari warga dan sekaligus survei terhadap kelayakan tempat yang akan dijadikan site atau lokasi dimana desain tersebut akan diaplikasikan oleh tim ARKOM dan UC.

9. Penyusunan panduan aplikasi desain dengan perhitungan yang sudah dilakukan oleh kedua tim serta pendokumentasian.

10. Aplikasi desain modul unit karantina portable ini disosialisasikan kepada masyarakat kampung studi dan kemudian bersama pihak terkait lainnya mulai membangun sesuai tahapan yang sudah ada dalam panduan desain.

\section{Publikasi.}

Adapun bentuk evaluasi dalam pelaksanaan ini merupakan bagian yang penting yang akan terjadi pada setiap prosesnya dan evaluasi tersebut merupakan bentuk penyamaan persepsi antara tim desainer sebagai fasilitator dan masyarakat sekitar sebagai pengguna, namun yang menjadi poin penting adalah bagaimana program ini dapat berlanjut. Selaras dengan tujuan dari kegiatan ini bahwa desain modul unit karantina portable ini yang sudah diaplikasikan menjadi prototype untuk nantinya dapat dikembangkan dimasing-masing daerah yang terdampak musibah dengan pengaplikasian yang relatif mudah, murah dan cepat.

Sebagai unit percontohan, dibuat modul unit isolasi yang akan dipasang di Dupak Magersari. Durasi pelaksanaan aktivitas pengabdian masyarakat ini dilaksanakan mulai dari 27 Agustus 2020 sampai dengan 27 Maret 2021. Detail aktivitas mulai dari persiapan sampai publikasi dapat dijelaskan melalui Tabel 1.

\section{HASIL DAN PEMBAHASAN}

Dalam prosesnya pembuatan Modul Unit Karantina Portable ini melalui tahapan pengumpulan data yang dilakukan bersama tim ARKOM pada bulan agustus-oktober 2020 untuk mengetahui kondisi area yang dijadikan studi, identifikasi tersebut dilakukan dengan survei lapangan, diskusi dengan kader lingkungan dan beberapa warga yang memiliki keluarga yang terdampak, serta dengan satgas covid-19 kampung. Setelah mendapatkan data-data terkait kondisi fisik dan nonfisik, tahap selanjutnya adalah memetakan permasalahan dengan menganalisa data-data tersebut, terkait kondisi rumah yang saling berdempet, sirkulasi dalam rumah yang relatif kurang, luasan ruang yang tidak sesuai standart ruang dalam rumah sehat serta pemilihan area studi kampung tepi rel dipilih karena area perkampungan ini jarang disentuh pihak Pemerintah sebab mayoritas warganya yang belum memiliki identitas sebagai penduduk Kota Surabaya, dengan kata lain warga didominasi oleh penduduk pendatang. 
Tsbel 1. Jadwal Kegiatan Pengabdian Masyarakat

\begin{tabular}{|c|c|c|c|c|c|c|c|c|c|c|}
\hline \multirow{2}{*}{ No } & \multirow{2}{*}{ Jenis Kegiatan } & \multicolumn{9}{|c|}{ Tahun 2020-2021 } \\
\hline & & 7 & 8 & 9 & 10 & 11 & 12 & 1 & 2 & 3 \\
\hline 1 & Pengajuan proposal & & & & & & & & & \\
\hline 2 & Literatur dan koordinasi awal & & & & & & & & & \\
\hline 3 & Persiapan penelitian dan diskusi dengan warga & & & & & & & & & \\
\hline 4 & Pengamatan lapangan & & & & & & & & & \\
\hline 5 & Wawancara dengan warga dan tim satgas covid kampung & & & & & & & & & \\
\hline 6 & Pengolahan data & & & & & & & & & \\
\hline 7 & Proses Analisa & & & & & & & & & \\
\hline 8 & Proses desain unit isolasi & & & & & & & & & \\
\hline 9 & Assessment desain unit isolasi dari standar kesehatan. & & & & & & & & & \\
\hline 10 & Diskusi desain awal bersama beserta revisi berdasarkan feedback warga & & & & & & & & & \\
\hline 11 & Pembuatan prototype di workshop & & & & & & & & & \\
\hline 12 & Penyusunan panduan aplikasi desain & & & & & & & & & \\
\hline 13 & Pemasangan modul unit karantina portable di lokasi & & & & & & & & & \\
\hline 14 & Publikasi, Penyusunan laporan akhir dan keuangan & & & & & & & & & \\
\hline
\end{tabular}

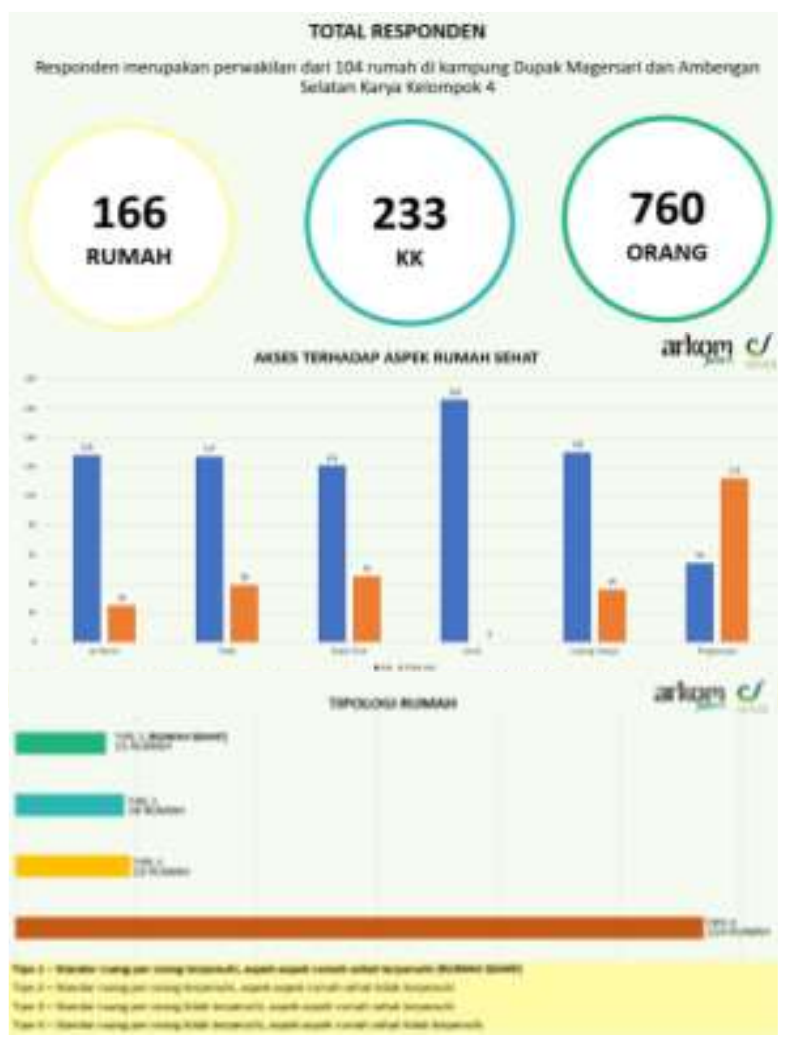

Gambar 5. Data Hasil Survei 2 Kampung Tepi Rel (Sumber: Dokumentasi ARKOM, 2020)

Setelah mengetahui bagaimana kondisi fisik rumah-rumah warga dilokasi studi, maka selanjutnya adalah melakukan diskusi terlebih kepada keluarga-keluarga yang memiliki anggota yang terpapar serta para kader kampung sebagai satgas covid-19 kampung. Lokasi terpilih yang dijadikan percontohan untuk pemasangan unit isolasi portable ini adalah kampung tepi rel Dupak Magersari. Berdasarkan hasil diskusi bersama warga lokasi untuk peletakkan modul unit isolasi portable pada lahan bersama milik warga yang terletak di bagian depan kampung untuk mempermudah akses dari jalan raya dan dekat dengan area terbuka.

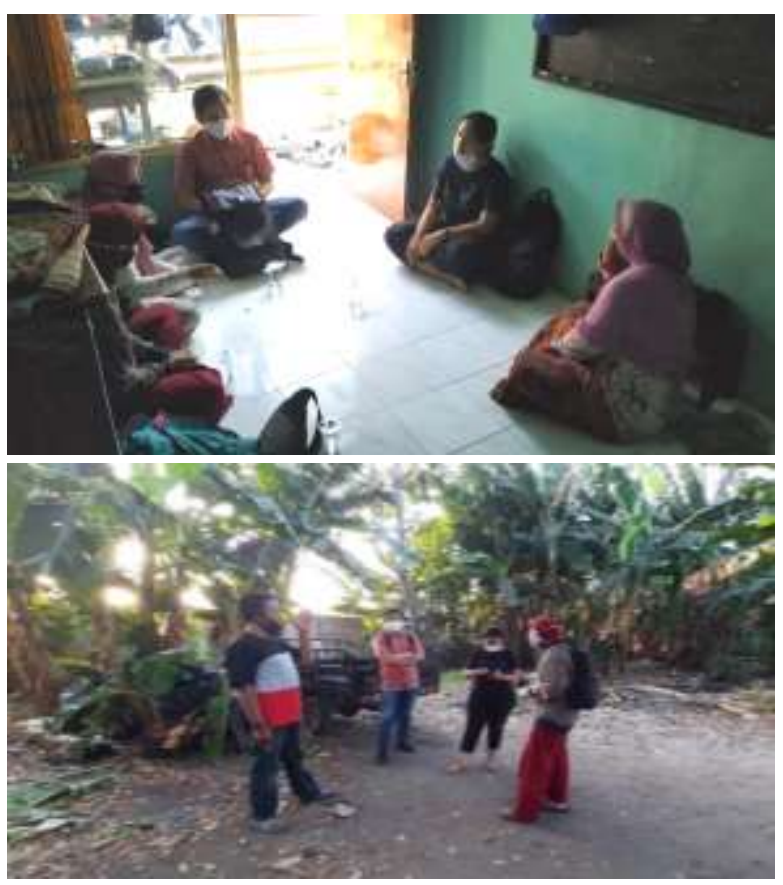

Gambar 6. Diskusi Lokasi Unit Karantina Dengan Kader Kampung Tepi Rel (Sumber: Dokumentasi Pribadi, 2020)

Dari hasil diskusi penentuan lokasi pemasangan modul unit karantina portable dan analisa data mengenai kondisi fisik dan non-fisik area kampung tepi rel, maka didapatkan beberapa parameter desain meliputi:

1. Desain unit modul harus memperhatikan kondisi lingkungan kampung yang padat penduduk sehingga ukuran tidak terlalu besar dan mampu menampung beberapa orang.

2. Unit modul harus memiliki sirkulasi udara yang baik.

3. Memiliki akses yang mudah dijangkau baik oleh keluarga maupun kerabat tanpa mengesampingkan standart protokol kesehatan.

4. Mudah dalam pengaplikasiannya, material yang umum didapatkan, ringan dan awet. 
Dari parameter tersebut dapat diusulkan desain modul unit karantina portable (gambar 7) dirancang dan kembali didiskusikan bersama warga. Adapun komponen panduan dalam desain modul unit karantina portable itu sendiri harus menggunakan sistem struktur bongkar pasang, dan memiliki bahan material rangka bangunan dari double canal $\mathrm{C}$ atau besi hollow, yang dirakit per portal struktur. Kemudian bangunan ini dilengkapi dengan dinding panel unit yang terbuat dari rangka galvalum dan memiliki pelapis dalam dan luar dari material polycarbonate yang transparan untuk memaksimalkan pencahayaan alami yang didapat dari terang langit serta bagian dinding dengan material polycarbonate yang tidak transparant untuk membatasi privasi pasien. Secara konsep bangunan modul unit isolasi komunal ini memiliki bagian bangunan yang terpisah, terlebih pada bagian atap dengan bagian dinding, sehingga menambah ruang untuk sirkulasi udara yang sangat diperlukan pasien. Untuk memaksimalkan sirkulasi udara tersebut, unit modul ini memiliki jendela dibeberapa panel dindingnya pula yang dapat dibuka tutup sesuai kebutuhan. Aliran udara penting dilakukan untuk mencegah terjadinya penularan dan membuat ruang udara semakin sehat.

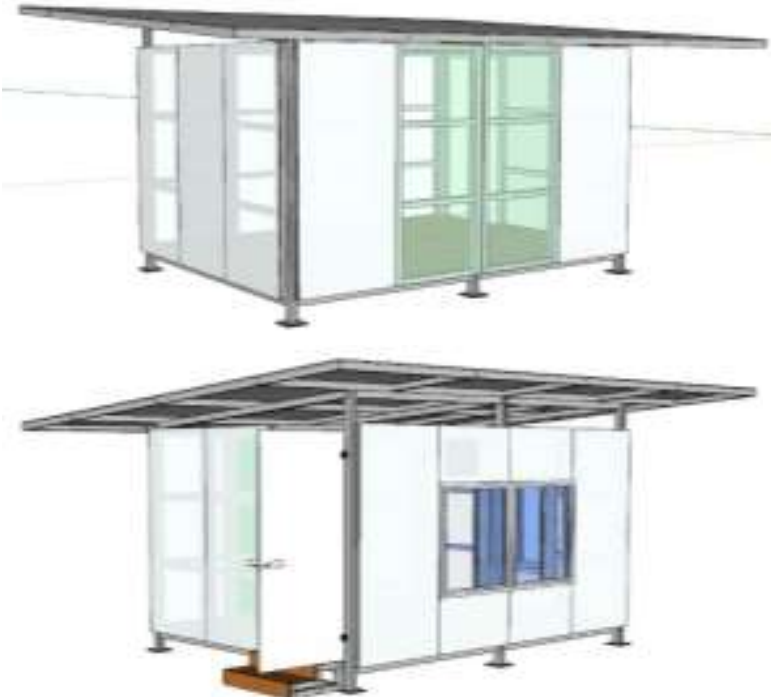

Gambar 7. Desain Unit Karantina Komunal Portable (Sumber: Dokumentasi Pribadi, 2020)

Sebagai percontohan, prototype unit karantina portable ini diaplikasikan di kampung tepi rel Dupak Magersari - RT 1/RW 9 Jepara, Bubutan, Surabaya pada tanggal 09 Maret 2021 bersama tim dosen Arsitektur Interior Universitas Ciputra, Arkom Surabaya dan warga Dupak Magersari. Prototype unit karantina portable ini diharapkan dapat dikembangkan lebih lanjut untuk permukiman informal padat lainnya, terutama dengan pengaplikasian yang mudah dan cepat. Proses pemasangan unit karantina portable ini dapat ditunjukkan melalui gambar berikut.

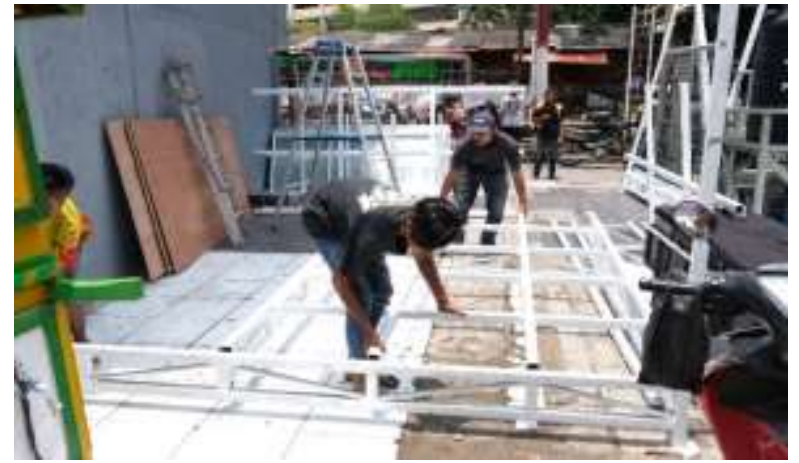

Gambar 8. Proses Pemasangan Rangka Lantai Unit Isolasi (Sumber: Dokumentasi Pribadi, 2020)

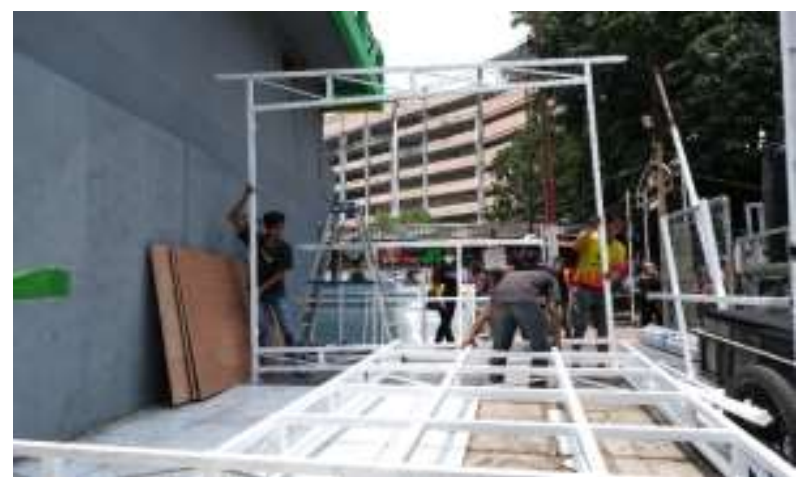

Gambar 9. Proses Pemasangan Rangka Dinding Unit Isolasi (Sumber: Dokumentasi Pribadi, 2020

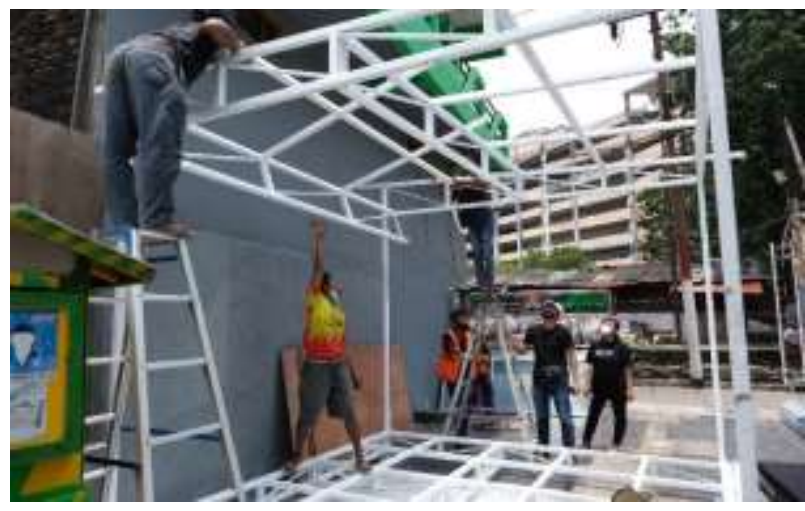

Gambar 10. Proses Pemasangan Rangka Atap Unit Isolasi (Sumber: Dokumentasi Pribadi, 2020)

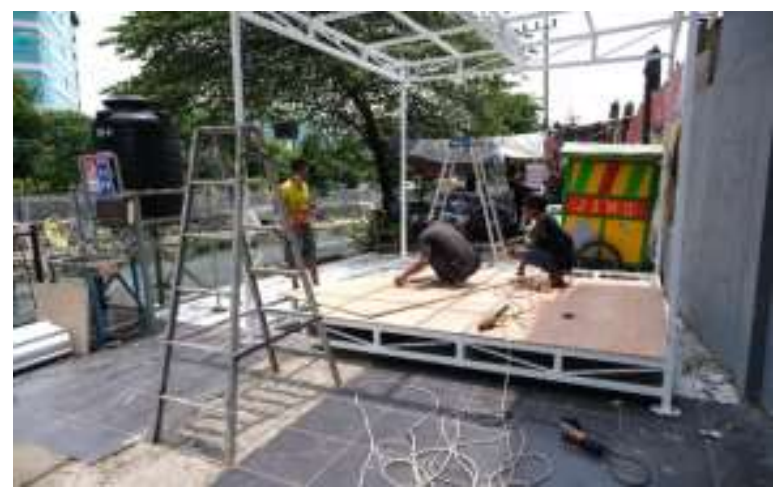

Gambar 11. Proses Pemasangan Penutup Lantai Unit Isolasi (Sumber: Dokumentasi Pribadi, 2020) 


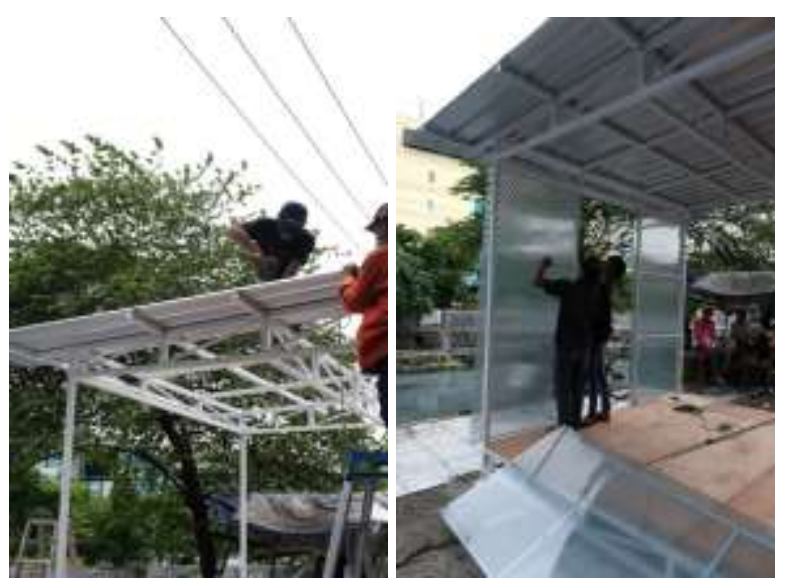

Gambar 12. Proses Pemasangan Penutup Atap dan Panel Dinding Unit Isolasi (Sumber: Dokumentasi Pribadi, 2020)

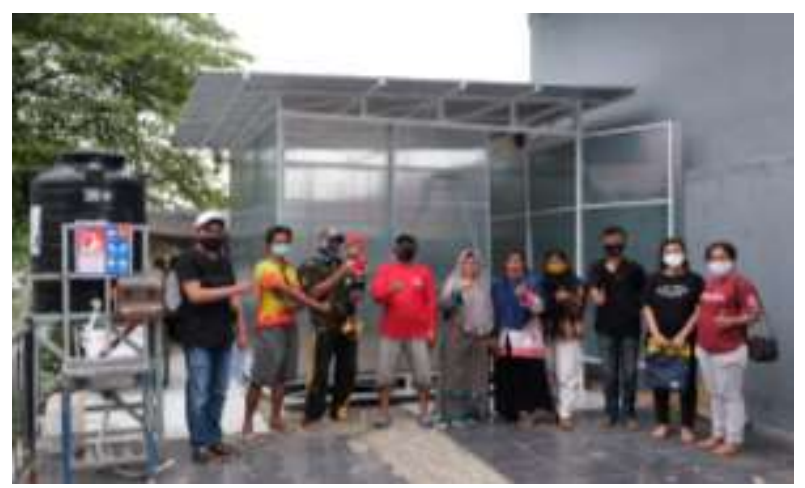

Gambar 13. Serah Terima Unit Isolasi kepada Perwakilan Warga Dupak Magersari (Sumber: Dokumentasi Pribadi, 2020)

\section{SIMPULAN DAN REKOMENDASI}

Pelaksanaan kegiatan pengabdian masyarakat modul unit karantina portable didesain partisipatif dari masyarakat yang dimulai dengan kegiatan pengumpulan data yang dilakukan dengan survei, observasi atau identifikasi permasalahan secara fisik dan non-fisik serta interview terhadap pihak-pihak yang terkait. Tahap selanjutnya adalah pemetaan permasalahan yang menjadi parameter untuk dirumuskan menjadi solusi dalam bentuk desain, pengambilan solusi dilakukan bersama pihak-pihak terkait dengan mengadakan diskusi-diskusi. dari tahap tersebut didapatkan beberapa parameter desain meliputi; desain unit modul harus memperhatikan kondisi lingkungan kampung yang padat penduduk, dengan ukurannya yang tidak terlalu besar. Mampu memuat beberapa orang, unit modul harus memiliki sirkulasi udara yang baik. memiliki akses yang mudah dijangkau baik oleh keluarga maupun kerabat tanpa mengesampingkan standart protokol kesehatan. Mudah dalam pengaplikasiannya, material yang umum didapatkan, ringan dan awet. Hasil desain modul unit karantina portable itu sendiri harus menggunakan sistem struktur bongkar pasang, dan memiliki bahan material rangka bangunan dari double canal $\mathrm{C}$, yang dirakit per portal. Kemudian dinding panel unit yang terbuat dari rangka galvalum dan memiliki pelapis dalam dan luar dari material polycarbonate yang transparan untuk memaksimalkan pencahayaan alami serta polycarbonate yang tidak transparan untuk membatasi privasi pasien. Untuk memaksimalakan sirkulasi udara unit modul ini memiliki jendela dibeberapa panel dindingnya dan memanfaatkan ruang diantara atap untuk mengalirkan udara. Pelaksanaan hasil desain dilakukan bersama oleh warga kampung dan diawasi oleh tim sebagai fasilitator, sehingga warga merasa memiliki terhadap desain maupun unit modul yang dihasilkan.

\section{UCAPAN TERIMAKASIH}

Ucapan terima kasih kepada masyarakat kampung tepi rel Dupak Magersari - RT 1/RW 9 Jepara, Bubutan dan kampung Ambengan Selatan Karya Kelompok 4 RT 1/RW 5, Pacarkeling, Kota Surabaya, serta komunitas ARKOM wilayah Surabaya yang berkontribusi bersama tim melakukan survei terhadap kelayakan rumah tinggal, menyediakan media penyuluhan kepada masyarakat. Terlebih untuk Universitas Ciputra Surabaya yang telah ikut serta dalam pendanaan terbangunnya Modul Unit Karantina Portable serta pihak LPPM yang telah membantu dalam setiap proses administrasinya.

\section{DAFTAR PUSTAKA}

Cluster, S. (n.d.). 5 ways Shelter and Settlements programs help mitigate the spread of COVID19. ShelterCluster.org/COVID19

Kusmadiana, I. H., Hodgkin, D., \& Amri, A. (2020). Panduan Penyiapan Fasilitas Shelter untuk Karantina dan Isolasi terkait COVID-19 Berbasis Komunitas. https://covid19.go.id/p/proto$\mathrm{kol} /$ panduan-penyiapan-fasilitas-shelteruntuk-karantina-dan-isolasi-terkait-covid-19berbasis-komunitas

Listijono, John Budi H. 2020. "Apa Yang Kita (GBCI) Bisa Pelajari Dari Pandemi Covid-19,".

Morawska, Lidia, Julian W. Tang, William Bahnfleth, Philomena M. Bluyssen, Atze Boerstra, Giorgio Buonanno, Junji Cao, et al. 2020. "How Can Airborne Transmission of COVID-19 Indoors Be Minimised?’ Environment International 142 (May). https://doi.org/10.1016/j.envint. 2020.105832 .

Sundari, Titi, Vivi Lisdawati, Jahiroh, Ehwan Zunaidi, Deki Indrawanto, Farida Murtiani, Yohana, and Maya Marinda Montain Temmasonge Radi Pakki. 2017. "Peran Sistem Tata Udara Dalam Pencegahan Dan Pengendalian Infeksi Di Ruang Isolasi Airborne RSPI Prof. 
Dr. Sulianti Saroso Tahun 2017." The Indonesian Journal of Infectious Diseases 4 (1).

Widodo, J. (2020). Petunjuk Teknis Pelayanan Puskesmas Pada Masa Pandemi Covid-19.

World Health Organization. (2020). Laboratory biosafety guidance related to coronavirus disease (COVID-19). Interim Guidance, 19 March, 1-5. https://doi.org/10.1016/j.ccm.2016.11.007
Wu, F., Zhao, S., Yu, B., Chen, Y. M., Wang, W., Song, Z. G., Hu, Y., Tao, Z. W., Tian, J. H., Pei, Y. Y., Yuan, M. L., Zhang, Y. L., Dai, F. H., Liu, Y., Wang, Q. M., Zheng, J. J., Xu, L., Holmes, E. C., \& Zhang, Y. Z. (2020). A new coronavirus associated with human respiratory disease in China. Nature, 579(7798), 265-269. https://doi. org/10.1038/s41586-020-2008-3 